\title{
Jan Simons
}

\section{Az iPhone és a YouTube között: a filmek mozgásban}

\begin{abstract}
Absztrakt
A fényképezôgéppel és videokamerával felszerelt 3G mobiltelefon éppen akkor jelent meg, amikor a YouTube népszerúvé vált. Bár e két fejlesztés elkerülhetetlenül összetalálkozott, a mobiltelefonos film máshová is eljutott, például a mobiltelefonos filmeknek szentelt fesztiválokra. A gyorsan elôretörő - most pedig fokozatosan visszaszoruló - fesztiválok megakadályozták, hogy a viszonylag konzervatív filmes kultúra lemaradjon az új technológiák nyújtotta fejlesztési lehetôségekrôl, valamint elôsegítették, hogy a filmkészítôk és producerek viszonylag zárt köre bekapcsolódhasson a kialakuló részvételi kultúrába. Miközben érzékenyítették a filmmúvészet területét az újonnan megjelenố technológiákra, szereplôkre és gyakorlatokra, légmentesen el is zárták azt attól az „amatôr kultusztól”, amely a YouTube felemelkedéséhez vezetett. A szerző alaposan megvizsgálja a kontextust, illetve a mobiltelefonos filmek szerepét a digitális média perspektívájából, rámutatva, hogy a mozgókép milyen új formákkal és funkciókkal gazdagodik a kortárs képernyốk és tartalmak sokszínú világában. Hiszen a kortárs a hibridizációs folyamatok a filmet is átalakították: fô feladata, a filmszínházak falain kívül, már nem a reprezentáció, hanem a kommunikáció.
\end{abstract}

\section{Szerzô}

Dr. Jan Simons docens a University of Amsterdam Médiatudományi Tanszékén. Kutatási területei közé tartozik a filmelmélet mellett a fotográfia, az újmédia és a játékelmélet. Kutatásai középpontjában az újmédia kiváltotta konvergencia és divergencia folyamatok állnak. Playing the Waves: Lars von Trier's game cinema (Amsterdam University Press) címú kötete 2007-ben jelent meg.

https://doi.org/10.31176/apertura.2019.14.2.3 


\section{Jan Simons}

\section{Az iPhone és a YouTube között: a filmek mozgásban}

\section{Digitális filmek: on- és offline helyszínek}

Véletlen egybeesés - már ha valóban véletlenrôl van szó -, hogy a fényképezőgéppel és videokamerával felszerelt $3 \mathrm{G}$ mobiltelefonok éppen akkor jelentek meg, amikor a web 2.0 ikonjának számító YouTube népszerúvé vált. A 2004-ben világszerte forgalmazott mobiltelefonok kétharmada videokamerás telefon volt; a YouTube hivatalosan 2005 novemberében indult az Egyesült Államokban, ezt követték 2007-ben az európai, latin-amerikai és ázsiai megjelenések. Mivel a videokamerával felszerelt telefon minden felhasználót potenciális filmkészítôvé tett, a YouTube pedig ingyenes felületet biztosított a saját készítésú filmek megosztására, terjesztésére és bemutatására, így e két fejlesztés elkerülhetetlenül összetalálkozott. Ennyi a lényeg, a többi pedig, mondhatni, történelem. De valóban az?

Egyfelôl a fenti állítás helytálló: 2006-ban a YouTube bejelentette, hogy a napi látogatószám elérte a 100 milliót, a felhasználók pedig több mint 65000 videót töltenek fel naponta. 43\%-os piaci részesedésével és több mint 2 milliárdos napi nézettségével 2010-re a YouTube az Egyesült Államok legnagyobb online videomegosztó webhelyévé vált. Forgalmának 70\%-át az Egyesült Államokon kívül realizálja, havonta több százmilliós nézettséget regisztrál csak mobil eszközökön, így ma már a harmadik leglátogatottabb internetes weboldal a Google és a Facebook után. ${ }^{[1]}$ Természetesen a YouTube-on az amatôr filmkészítók mellett professzionális és kereskedelmi filmes cégek, valamint tévétársaságok tartalmai is megtalálhatók. Ezek jelentôs része „illegálisan” feltöltött, szerzôi jogi védelem alatt álló anyag. Bár nehéz pontos számadatokra hivatkozni, úgy tûnik, hogy a sok esetben mobileszköz vagy számítógép kamerájával rögzített, „csináld magad” filmek alkotják a YouTube-tartalmak jelentôs részét. 
Másfelól azonban a mobiltelefonos film egyéb helyszínekre is eljutott, például a mobiltelefonos filmeknek szentelt fesztiválok világába, melyeknek változatos elnevezései közül csupán néhányat sorolok fel: „zsebfilmek” [„pocket movies”, „pocket cinema”], „mobilfilmek” [,cellular movies”], „Ciné Pocket”, „Movil Film”, „Mobi Fest”, „rövidfilmek”. Csak néhány évvel a vélhetôleg első, 2004-ben Atlantában megrendezett mobiltelefonos filmfesztivál után szinte a világ minden jelentôsebb nagyvárosa elkezdte megrendezni saját fesztiválját. Ezenkívül számos hagyományos filmfesztiválköztük a Sundance Filmfesztivál, a San Franciscó-i Nemzetközi Filmfesztivál, a Tribeca Filmfesztivál, az Edinburgh-i Nemzetközi Filmfesztivál, a Rotterdami Nemzetközi Filmfesztivál, sốt még a Cannes-i Filmfesztivál is - külön szekciót nyitott ezeknek az alkotásoknak. [2]

Ahogyan azt elôre sejteni lehetett, az ilyen események helyi és nemzetközi változatai egyaránt megjelentek. Ezeket olyan mobilgyártó cégek szponzorálták, támogatták, mint az okostelefont megelôzố idôszakban a 3G készülékek terén piacvezetố szerepet játszó Nokia, a Samsung, a Vodafone és sokan mások, akik tartalmat kerestek hardware-eik és szolgáltatásaik számára. A fesztiválokon tárt karokkal fogadták a 3G mobiltelefonnal rendelkezô, „csináld magad” filmkészítôket éppúgy, mint „a tapasztalt filmrendezôket, egyéb szakmabelieket, egyetemistákat és nézôket.” Azt remélték, hogy így „beláthatóvá, elôre tervezhetôvé, feltérképezhetôvé válik ez az új alkotási területet”, ahogyan egyébként azt az első, 2005-ben megrendezett párizsi Festival Pocket Films meg is fogalmazta. ${ }^{[3]}$ Ez a megfogalmazás önmagában és önmagáról is sokatmondó: a mobiltelefonos film mint találmány megelôzte a gyakorlati megvalósulást. Ezek a terminusok és a köréjük szerveződô események nem egy új, feltörekvô jelenségre utaltak, mely még meghatározásra és besorolásra vár - funkciójuk sokkal inkább az akkor még újnak számító technológia által létrehozott ûr betöltése volt.

A gyorsan elôretörő - most pedig fokozatosan visszaszoruló - fesztiválok a mobilgyártók és a telekommunikációs szolgáltatók tartaloméhségén túl két célt szolgáltak. Elôször is - a független filmkészítésben, a viszonylag olcsó és hordozható digitális videokamera megjelenésével, már jó tíz éve megtapasztalt változások után - megakadályozták, hogy a viszonylag konzervatív filmes kultúra lemaradjon az új technológiák nyújtotta, potenciális, jövóbeli fejlesztésekrôl. Vagyis azt remélték, hogy a mobiltelefon kamerája rátalál saját Lars von Trier-jére. És csakugyan, 2005-ben a dél-afrikai rendező, Aryan Kaganof elkészítette az SMS Sugar Man címú alkotást, ami vélhetôleg az egyik elsô játékfilm hosszúságú, teljes egészében mobiltelefon-kamerával felvett film. [4] Másodszor azzal, hogy a mobiltelefonos filmfesztiválok mozivászonra engedtek bárkit, aki közkinccsé kívánta tenni mobiltelefonnal készített alkotását, elôsegítették, hogy a filmkészítôk és producerek viszonylag zárt köre bekapcsolódhasson a kialakuló részvételi kultúrába, és olyan alkotásokkal rukkolhasson eló, mint amilyen a Dogma 2.0. [5] 


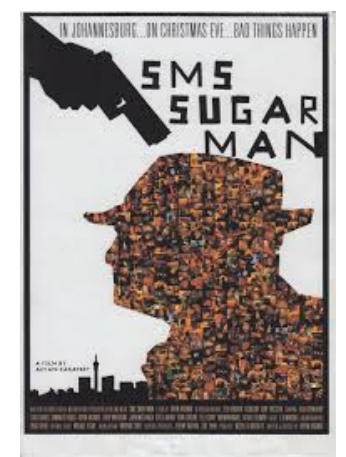

SMS Sugar Man.

Aryan Kaganof, 2005

Ugyanakkor ez a két funkció egy újabb kettôsséget hozott magával. A mobiltelefonos

filmfesztiválok előretörése kísérlet volt arra, hogy az új technológiákat és a tehetséges, innovatív filmrendezőket a filmmúvészet már létezô struktúráiba és múködési módjaiba illesszék. Könnyen elképzelhetố továbbá, hogy a mobiltelefonos filmfesztiválok legfóbb stratégiai funkciója abban állt, hogy érzékenyítsék a „filmmúvészet területét” az újonnan megjelenő technológiákra, szereplôkre és gyakorlatokra, ugyanakkor légmentesen elzárják azt attól az „amatôr kultusztól”, amely a YouTube felemelkedéséhez vezetett. ${ }^{\left[{ }^{[6]}\right.}$ Rendszerelméleti szempontból a mobiltelefonos filmfesztiválok virágzása annak a megújulást célzó alkalmazkodási stratégiának a részeként értelmezhetô, amely a „mozit mint intézményt” az elmúlt több mint száz évben jellemezte. Vagyis a YouTube-ra adott válaszként. Amennyiben ez igaz, akkor felmerül a kérdés, hogy a mobiltelefonos filmfesztiválok utóbbi években tapasztalható, fokozatos visszaszorulása a stratégia sikerének vagy éppen kudarcának a tünete. Vajon a mobiltelefonos filmfesztivál a 21. századi filmkultúra előfutára vagy éppen az új digitális médiakultúra utóvédharcosa volt? Átfogalmazva a kérdést: a mobiltelefonos alkotások a filmkultúra vagy a digitális kultúra részei?

\section{Zsebfilmek [Pocket Films]: Kisujjunkban van a film}

A mobiltelefonos film modernista felfogástól vezérelt zászlóvivôi azt várták, hogy az új technológiák újfajta filmkészítési módokat, új filmmúvészeti formákat, formátumokat, stílusokat és történeteket is hoznak. A mobiltelefonos filmfesztiválok pedig a tapasztalt, az ígéretes és az önjelölt filmrendezôk játszóterévé válhatnak, ahol mindenki kedvére kísérletezhet a rendelkezésre álló új eszközökkel, s közben feltérképezhetik az eszközök lehetôségeit és korlátait. Mivel a mobiltelefonos film nem egy már létezô filmtípus vagy filmes múfaj, sokkal inkább a 3G telefonok piaci megjelenése és gyors elterjedése által kiváltott ötlet, elsô kérdésként az merülhet fel, hogy mi is tulajdonképpen a mobiltelefonos film. A válasz pedig távolról sem egyszerú.

Elég egy pillantást vetni néhány fontosabb mobiltelefonos filmfesztivál részvételi felhívására, hogy a meghatározást körülvevô bizonytalanságra fény derüljön. A német Mobile Film Festival és a francia Festival Pocket Films a „zsebfilm” vagy a „mobiltelefonos film” kategóriáját mobiltelefonkamerával rögzített filmként definiálják [,films tournés avec téléphone mobile” és „Filme... die mit 
einem Mobiltelefon gedreht wurden”], a torontói Mobifest viszont „mobiltelefonra készített” filmekról beszél. [7] Annak ellenére, hogy a mobiltelefon az elsô olyan „új eszköz”, amely ahogyan azt az első, 2005-ben megrendezett, párizsi Festival Pocket Films beharangozójában olvashatjuk - egyszerre „kamera, projektor és képernyő [écran à diffusion], a mobiltelefonnal készített filmek nem feltétlenül mobilon történô lejátszásra készülnek. ${ }^{[8]} \mathrm{Az}$ elôbb említett fesztivál például meghirdet „Filmek nagy vászonra” [Films pour grand écran] és „Filmek zsebvászonra” [Films pour écran de poche] kategóriát is. A kanadai Mobifesten az „Animáció” mellett a „Mobiltelefonnal rögzített filmek” kategóriája is a programba került. Ezek a besorolások azt mutatják, nem minden mobiltelefonos film készül mobillal, és nem minden mobiltelefonos film készül mobiltelefon „zsebképernyőjére”. Ahogy Roger Odin, francia filmelméleti szakember a „zsebfilm közönségérôl” írt esszéjében fogalmaz, a mobiltelefonnal rögzített filmek mozifilmek [„Les films tournés avec téléphone mobile sont des films de cinéma”], mivel nagy képernyőre lettek elgondolva. [9]

Hogy tovább bonyolítsuk a dolgokat, bár mobiltelefonnal lehet filmet készíteni, bemutatni és terjeszteni - a felhasználónak lehetôsége van arra, hogy mobiltelefonról közvetlenül a YouTubera, Flickr-re töltsön fel filmeket, fényképeket vagy olyan közösségi oldalakra, mint a Facebook vagy a MySpace -, a felvétel és a bemutatás közé általában beékelődik a vágás és az utómunkálatok fázisa, amelyre a mobiltelefonok nem igazán alkalmasak. A német Mobifest engedélyezi a „mobilon kívüli eszközön történô vágást is” [„Die Filme können innerhalb oder außerhalb der Telephone geschnitten werden"], a brüsszeli Ciné Pocket fesztivál pedig kimondottan javasolja a mobiltelefonnal készített filmek számítógépes vágását [„,Mais il reste souhaitable de copier et de monter le film sur ton pc"]. ${ }^{[10]}$ A vágás ugyanakkor nem pusztán a snittek kiválasztása és elrendezése, általában hang és feliratok, színkorrekció, szürők, virtuális kameramozgások, osztott képernyők, egymásra fényképezés hozzáadását, valamint - mivel a számítógép számára közömbös az általa feldolgozott adatok eredete - speciális effektek és számítógépes képek megalkotását is jelenti. Valójában mit jelent tehát a „mobiltelefon kamerájával készített” vagy „rögzített” kifejezés? Mint ahogy az a fentebb említett torontói Mobifest kategóriáiból is kiderül, a különböző mobiltelefonos filmfesztiválokon részt vevő alkotások gyakran kamera nélkül, teljes egészében számítógépen megalkotott animációs filmek.

Amennyiben a rögzítési és utómunkálati technikák alapján nem lehet egyértelmúen elkülöníteni a mobiltelefonos filmeket más típusú filmektôl, elképzelhetô, hogy „a mobiltelefonra készült filmeket” kellene ezzel a terminussal jelölni. A „zsebfilm” [pocket cinema] kifejezés is mintha ezt erôsítené, hiszen megidézi a „zsebkönyvek” - mai nevükön puha kötésú könyvek hordozhatóságát, könnyen emészthetôségét. Természetesen bármilyen könyvet ki lehet adni mind kemény kötésben, mind zsebkönyv-formátumban, és számos klasszikus szöveg jelent meg, szélesebb olvasóközönséget megcélozva, olcsó, zsebkönyv-kiadásban. Mivel a zsebkönyvet arra találták ki, hogy könnyedén magunkkal vihessük bárhová, és a hosszú, koncentrált olvasásnak nem igazán kedvezố körülmények között is olvashassuk, például munkába utazás közben, a zsebkönyvek hozzájárultak a könnyen emészthetô, igen közhelyes és felejthetô irodalmi stílusok - 
krimi, thriller, kalandos, horror vagy romantikus szerelmi történetek - elterjedéséhez. Annak ellenére, hogy ezeket a stílusokat nem kizárólag puha kötésben adták ki, mégis ennek a formátumnak a prototípusát képviselik, s erról bármelyik reptéri könyvesboltban megbizonyosodhatunk. Ugyanakkor ezen múfajok dominanciája a zsebkönyv-részlegen sokkal inkább magyarázható a különleges körülmények között történő olvasás megkönnyítését célzó, pragmatikus elgondolásokkal, mintsem a gyártás során alkalmazott anyagokkal és technológiákkal.

Vajon ugyanez elmondható a „zsebfilmekrôl”? Elvileg bármilyen filmet le lehet játszani mobiltelefon vagy más hordozható eszköz képernyôjén. Az Apple (amerikai) iTuneStore-ja például filmeket, televíziós show-músorokat, videoklipeket és számítógépes játékokat is ajánl iPhone-ra, iPodra és iPadre történô letöltésre és lejátszásra, implicit módon bizonyítva, hogy a mobiltelefonos filmek sem most, sem korábban nem korlátozódtak a mobiltelefonra, bár csak ez utóbbi alkalmas filmnézésre és -készítésre egyaránt. Mégsem hívta soha senki ezeket a letölthetô tartalmakat „mobil-” vagy „zsebfilmnek”, még akkor sem, ha kimondottan iPhone vagy iPad formátumban kaphatók. A legtöbb ilyen filmet, televíziós show-músort és videoklipet moziban vagy televízión történô megtekintésre, esetleg a filmvásznon elérhetô minőséggel hamarosan versenyre kelô, nagy felbontású, hatalmas képernyôs házimozi technológiára készítették. Ugyanúgy, ahogy a zsebkönyvek esetében már láttuk, részben technológiai, de fôként pragmatikus okokból kifolyólag, ezek az audiovizuális tartalmak, bár elvileg lejátszhatók mobileszközön, mégsem tekintendôk zsebfilmeknek.

Bár a mobileszközöket általában high-tech eszközként árusítják, és akként is tekintünk rájuk, képminôségük jócskán elmarad a moziban, televízión vagy akár a számítógép képernyôjén megszokott minôségtôl. Az LCD és plazma televíziók képernyôjéhez vagy a mozivászonhoz képest a mobiltelefon jóval kisebb méretú és viszonylag kis felbontású, alacsony képváltási frekvenciával, valamint szúk színtartományú képernyővel rendelkezik. Emellett mobiltelefonon vagy más hordozható eszközön általában „menet közben” nézünk filmet, hasonlóan ahhoz, ahogyan zsebkönyvet olvasunk; vagyis, repülögépre, vonatra vagy buszra várva, utazás közben, nyaralás alatt, a tengerparton. Olyan helyzetekben tehát, amelyek nem igazán kedveznek annak, hogy teljesen belemerüljünk egy játékfilm fiktív világába vagy egy dokumentumfilm hosszas fejtegetésébe. Leginkább azért, mert egymással versengó élmények sokasága jellemzi ezeket a helyzeteket: figyelmünket elterelô események, emberek, figyelmet követelő feladatok, nem megfelelô fényviszonyok, például túl erôs napsütés.

Csábító lenne ezeket a technológiai és pragmatikus kötöttségeket a mobiltelefonos film megkülönböztetô jegyeit meghatározó, médiumspecifikus esztétika jellemzőiként azonosítani. A mobiltelefonos filmek korai időszakában már történtek - tipikusan modernista - kísérletek ezen jellemzốk azonosítására. Például Juliana Pierce, ausztrál újmédia tanácsadó és producer, a „negyedik képernyô” nevet adta a mobiltelefon kijelzójének, azt sugallva, hogy a film a mozivászon, a TV és videó képernyôje, valamint a számítógép monitora mellett egy újabb felületre bukkant. Pierce azt is megállapítja, hogy érdemes „kerülni a totálképek, svenkek, térhangzás, hangulatvilágítás és a részletgazdag elemek alkalmazását a mobiltelefonos filmekben”. [ 11] 
Reinhard W. Wolf, német kritikus szerint a mobiltelefon kis méretú kijelzôje szinte kötelezôvé teszi a közelik használatát, miközben az alacsony képváltási frekvencia korlátozza a gyors vágást éppúgy, mint a szereplôk és a kamera gyors mozgását. A szúk színtartomány pedig nagy és élénk színú felületek alkalmazását teszi szükségessé. ${ }^{[12]}$ Továbbá a zsebfilmeket nem érdemes bonyolult hanghatásokra, párbeszédekre építeni, mivel a mobiltelefonok hangkapacitása szintén szerény a mai mozitermek és házimozik hi-fi felszereléséhez képest, de a mobiltelefonos filmnézést gyakran jellemzô zajos környezet miatt sem. Figyelembe véve a mobiltelefonos filmnézés leggyakoribb körülményeit, valamint a különbözô technológiai kötöttségeket, például a legtöbb mobileszköz korlátozott tárolókapacitását vagy a vezeték nélküli internetes kapcsolat (már ha egyáltalán elérhetô) sávszélességét, egyáltalán nem meglepő, hogy a korai kritika az egyszerú történetszövésû, rövid filmeket preferálja, világos, ám meglepő befejezéssel. Joe Miale, ausztrál filmrendezô úgy fogalmaz, hogy a nagyon rövid film ne karakter-, hanem „karikatúraközpontú” legyen. [13]

Ezen ajánlások alapján Isabella Rossellini minisorozata, a nyolc, nagyon rövid részból álló Green Porno ${ }^{[14]}$ tökéletes zsebfilm. Rossellini egy rovarpár hím tagját alakítja, és elmagyarázza, majd bemutatja, hogyan közösül az adott faj. Egyszerú, élénk színú jelmezeket visel, a díszlet szintén egyszerú és élénk színú. A leginkább talán gyerekrajzra emlékeztetô képeken pedig mintha keveredne az élôszereplős és az animációs látvány. Minden rész a szexuális aktus beteljesedésével, $\mathrm{s}$ esetenként annak halálos következményeivel ér véget, mindig világos, idônként vicces, $\mathrm{s}$ mindenképpen meglepő fordulatot hozva. A gyerekes forma és a felnôtt tartalom játékos dialektikája, az ökológiai nevelés és a pornográf kíváncsiság ötvözése révén a Green Porno a mobil eszközök új, ám technológiai szempontból éretlen „negyedik képernyője”, valamint felnôtt megfelelói, a mozi és a televízió közötti feszültséget allegorizálja. 


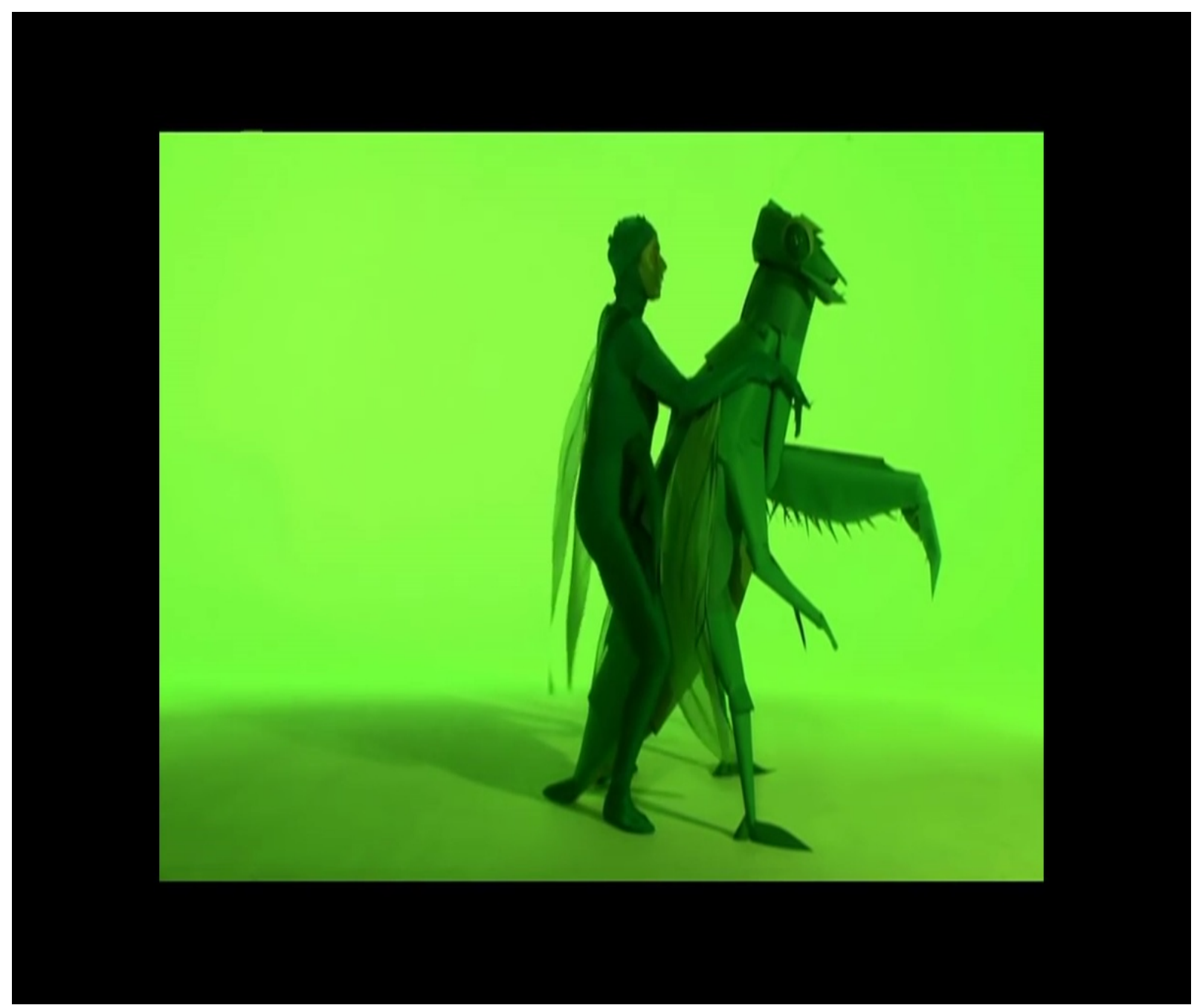

Imádkozó sáska (Praying mantis). Green Porno (Isabella Rossellini, 2008)

Bár a Green Porno a mobileszközök „negyedik képernyőjének” gondolatát alkalmazza, mégis a zsebfilmek ellentmondásos státuszát példázza. Nem mobiltelefon kamerájával, hanem profi filmstúdióban, profi felszereléssel rögzítették, és nem kizárólag mobiltelefonos forgalmazásra szánták. Hírnevet függetlenfilmes fesztiválokon szerzett, hozzáférni kizárólag streaming formátumban, a Sundance Filmfesztivál internetes oldalán lehet, valamint - ahogyan az várható volt - a YouTube-on. ${ }^{[15]}$ Isabella Rossellini, az olasz neorealista rendezô, Roberto Rossellini és a svéd színésznô, Ingrid Bergmann lánya, olyan filmek révén vált ismertté, mint David Lynch Kék bársony [BlueVelvet, 1986] és Veszett a világ [Wild at Heart, 1990] címú filmjei, illetve a holland filmrendezô, Jeroen Krabbé Left Luggage (1998) címú alkotása. Így azután Green Porno címú sorozatát sokkal inkább tekintették a film-ahogyan-ismerjük típusú terméknek, mintsem - a nagyon rövid filmek és a zsebfilmek mintájára - valami új elôfutárának. Vagy a Green Pornó szóhasználatával: nem valami újat létrehozó, hanem reprodukáló formáról van szó.

Jóllehet számos kritikus és producer, például Pierce, Wolf vagy Miale számára a mobiltelefon kötöttségei a mobiltelefonos filmesztétika megkülönböztetô jegyeit alkotják, ez az esztétika maga is a klasszikus hollywoodi film és az európai múvészfilm tiszteletre méltó hagyományaiból táplálkozó stiláris és formai repertoár viszonylag apró részhalmaza. ${ }^{[16]}$ A mobiltelefonos film 
éppen csak „remediatizálja” a már létezô „régi médiumok”, a mozi és a televízió ismerôs formáit és formátumait. ${ }^{[17]}$ Roger Odin, filmelméleti szakember egyrészt általánosságban, másrészt a mobiltelefonos filmfesztiválok kapcsán beszél a mobiltelefonos filmek remediatizáló funkciójáról. Odin úgy véli, hogy a mobiltelefonos film remediatizálja a filmkép és a valóság közötti indexikus kötés elvesztését azáltal, hogy felhívja a néző figyelmét a digitális filmgyártás során alkalmazott anyagokra, technikákra és eljárásokra. Véleménye szerint a mobiltelefonos filmek ugyanazt képviselik a kortárs mainstream filmekhez képest, mint az avantgárd és az experimentális filmek a korabeli mainstream filmekhez képest. ${ }^{[18]}$ A mobiltelefonos filmek legfontosabb funkciója az, hogy a kortárs digitális filmek nézôit emlékeztetik Godard-nak az elôzó évszázad hatvanas éveiből származó megfogalmazására: „Ce n'est pas une image juste; c'est juste une image” [a. m. „Nem egy pontos kép, pont csak egy kép”].

Bár a mobiltelefonos filmesztétika megalkotására tett kísérletek a lejátszásra szánt felület korlátaiban vagy a nézóre gyakorolt hatásban, nem pedig a gyártás módjában igyekeznek megragadni annak lényegét, az aktuális gyakorlatok és virtuális lehetôségek spektrumának egy szeletét azért lefedik. Egyrészt ezek a megközelítések a mobil eszközökön, illetve a házimozi képernyőjén vagy a filmszínházban történő filmnézés közötti felszínes hasonlóságok áldozatává válnak. Másrészt annak a modernista elképzelésnek a rabjai maradnak, mely szerint a médiatechnológiák saját, specifikus esztétikai tulajdonságokat és követelményeket hoznak létre. A digitális média perspektívájából közelítve, a mobiltelefonos filmek azonban teljesen más fényben kezdenek feltûnni.

\section{Mozgóképek: a képek mozgásban}

Pierce „negyedik képernyô" fogalma nyomán, Alex Munt kritikus a mobiltelefon kijelzôjét a számítógép képernyôjével együtt az S, vagyis kicsi [small], a nagyképernyôs televíziót az M, vagyis közepes [medium], a 2D-s mozivászont az L, vagyis nagy [large], míg az Imax mozik 3D-s vásznát az XL, vagyis az extra nagy [extra-large] kategóriába sorolta. ${ }^{[19]}$ Egy másik kritikus, Ted Brown újabb besorolást javasol: az elsô kategória az analóg mozivászon; a második az elektronikus televízió-képernyố; s a harmadik a digitális mobiltelefon-kijelzô. ${ }^{[20]}$ Ezek az osztályozások, akár a méretet, akár a technológiát veszik számításba, elsôsorban arról tanúskodnak, mennyire hiábavalóvá, átmenetivé és ingataggá vált bármilyen besorolás, mióta a vetítővászon és a képernyô elhagyta eredeti otthonát, a mozit és a nappalit. Mára a képernyő mindenhol jelen van olyannyira, hogy bármilyen, a mozivásznat kiindulópontként elgondoló kategorizáció a mozi privilegizált státuszát megórizni kívánó, reménytelenül elavult igyekezetnek túnik.

Sokkal beszédesebb mindaz, ami kimarad az osztályozásból: a „nagyvárosi kivetítôk”, vagyis azok a hatalmas, dinamikus hirdetôtáblák, amelyek egyre nagyobb számban díszítik városaink köztereit, utcáit, tereit; „túzfalakon” vagy épületeken elhelyezett videofalak; köztereken, tömegközlekedési eszközökön tájékoztatás, reklám vagy szórakoztatás céljából felszerelt nagy képernyôk; rock-koncertek vagy sportesemények alkalmával használt videofalak; a navigációs 
rendszerek kis képernyôje; DVD-lejátszók és játékkonzolok autóban vagy hajón, hogy csöndben maradjanak a gyerekek, hogy elfoglalják magukat a vendégek. Audiovizuális információval „kiterjesztett” terekről ma már nem csak a Times Square és a Piccadilly Circus jut eszünkbe. Ha véletlenül nincs egyetlen képernyô sem a közvetlen környezetünkben, akkor még mindig elővehetjük a mobiltelefont, az iPodot vagy az iPadet.

A fentebb említett osztályozásokra jellemzô szelektív vakság oka kézenfekvő: a kiválasztás elsődleges kritériuma nem a méret vagy a technológia, hanem a tartalom. A kategóriák csak filmek - játékfilmek vagy nagyon rövid filmek - nézésére alkalmas képernyőkre vonatkoznak. Vagyis nem képesek lefedni a kortárs képernyôk és tartalmak sokszínúségét, és így arra mutatnak rá, mennyire szúklátókörúvé válik az, aki a már létezô - s éppen „remediatizáció” elôtt álló - média perspektívájából közelíti meg az újmédiát. A képernyők burjánzását tapasztaljuk az otthonokban, irodákban, bevásárló központokban, stadionokban, múzeumokban, bárokban, várókban, repülôtereken, vonatállomásokon, buszokon, repülôkön és vonatokon. Változatos formájú és méretú képernyôk lepik el a privát szférát és a köztereket egyaránt. Ahogy a mozgókép elhagyja eredeti lakóhelyét, a mozit és a nappalikat, ez utóbbiak egy megjelenítési felületté válnak a sok közül. Ezekkel a változásokkal párhuzamosan, a mozgókép új formákkal és funkciókkal gazdagodik. A játékfilmek és televíziós show-músorok a jelenkori „vizuális kultúra” ikonjává vált, mindenütt jelen lévő, multifunkcionális mozgókép sajátos esetét képviselik.

Ironikus módon, a mozikból és a nappalikból kilépve, a mozgókép gyakran kerül szembe technológiai, gyakorlati és pragmatikus korlátokkal, melyek a már említett kritikusok, Pierce, Miale és Wolf által a zsebfilmek esetén azonosított kötöttségekhez hasonlítanak. Az óriáskivetítôkön - például image skineken és nagyvárosi kivetítôkön - megjelenített képek esetében gyakran nem megfelelőek a fényviszonyok, zajos a közvetlen környezet, és még a járókelők figyelméért is meg kell küzdeni, hiszen azt könnyen elvonják a különböző történések, utcai incidensek, a forgalom vagy éppen a többi képernyő. A viszonylag alacsony felbontás, képváltási frekvencia és a rossz megvilágítás miatt ugyanúgy nem ajánlatos részletgazdag képeket, panoráma-tájképeket, finom színeket, gyors vágásokat és kameramozgásokat alkalmazni, mint a mobiltelefonos filmek esetében. Ráadásul ezek a képek általában nélkülözik a hanghatásokat, hiszen azokat úgyis elnyelné a zajos városi környezet, legfeljebb csak fokoznák az egyébként is jelentôs hangzavart.

Mindezek mellett a városi járókelôk figyelme talán még rövidebb, mint a mobiltelefont használóké. A városlakó „úton van”, és meg kell osztania figyelmét az ôt érő, számos érzékszervi, társadalmi és kereskedelmi benyomás között: kognitív és perceptuális értelemben egyszerre több feladatot „lát el”. A mobiltelefon esetében már megfigyelt okokból kifolyólag tehát fontos, hogy az ilyen képernyôkön sugárzott tartalom rövid, világos, könnyen érthetô legyen. Az animációk, reklámfilmek és nagyon rövid filmek felelnek meg leginkább az óriásképernyők kívánalmainak. Vagyis a mobiltelefonos filmek esetén tapasztalt kötöttségek nem specifikusan az adott technológiához vagy a kijelző méretéhez, sokkal inkább a mozgókép befogadásának praktikus körülményeihez köthetôk. Következésképp, azok a múfajok, amelyek hagyományosan csak 
marginális szerephez jutottak a mozivásznon és a televízió képernyōjén, dominánssá váltak az óriás- és a miniképernyôkön. Az animációk, videoklipek és reklámfilmek mainstream szerepkörbe kerültek.

A világot benépesítô képernyôk sokasága ma már nem csak filmeknek ad otthont, ahogyan azt a filmszínházakban megszokhattuk. A mobiltelefonok és számítógépek képernyőit elsôsorban akkor használjuk, ha gépelünk, SMS üzeneteket vagy e-maileket írunk, írott vagy fényképes jegyzeteket készítünk, interneten keresgélünk, játszunk, számításokat végzünk, térképeket tanulmányozunk vagy telefonszámot, lakcímet keresünk. Mind az óriásképernyôket, mind a mobiltelefonok vagy egyéb hordozható eszközök miniképernyőit - ugyanúgy, ahogy az asztali gépek vagy laptopok képernyőit - arra használják, hogy szöveges üzeneteket, grafikákat, animációkat, fényképeket, térképeket, rajzokat, híreket, reklámokat, szórakoztató tartalmakat, közlekedési információkat jelenítsenek meg, nagyméretú nyilvános eseményeken instruálják a tömegeket, sporteseményeket és politikai gyúléseket közvetítsenek, valamint múalkotásokat, „zsebfilmeket” és egyéb, a szélesebb közönségnek bemutatkozni vágyó emberek által készített és feltöltött tartalmakat tekintsenek meg. $\left[{ }_{21}\right]$

Természetesen a különbözố tartalmak általános együttélését a médiumok többségének a digitalizálása tette lehetôvé. Mivel ezek ugyanúgy az egyesekból és nullákból álló, digitális nyelvet „beszélik,” nem csupán együtt élnek, de újabb és újabb konfigurációkba rendeződnek, boldogan vegyítve vagy cserélgetve a korábban egy-egy médiumot jellemzô tulajdonságokat, eljárásokat, formákat és formátumokat. A digitális technológiák révén a számítógépek a manovichi „metamédiummá” váltak, s nem csak a „filmmúvészetet, animációt, számítógépes animációt, speciális effekteket, grafikus designt és tipográfiát”, hanem a korábban „autonóm” médiumok „alapvetô technikáit, munkamódszereit, reprezentációs és kifejezési módjait” is vegyítik. ${ }^{[22]} \mathrm{A}$ grafikus felhasználói felületnek (GUI) köszönhetôen, addig tipikusan a filmmúvészetben használt eljárások, például a zoom vagy a svenk, szinte minden más alkalmazás számára is elérhetôvé vált. A számítógép képernyôjén ablakokban megjelenített tartalmak a felhasználóknak lehetôséget adnak arra, hogy kedvük szerint fel- vagy legörgethessenek, jobbra vagy balra svenkeljenek, adott részletekre rázoomoljanak. Bizonyos értelemben tehát minden médium „mozgóképpé” vált.

Maga a film is hatalmas változásokon ment keresztül ebben a hibridizációs folyamatban. Ma már nagyon nehéz az élőszereplôs részeket megkülönböztetni az animációtól, a beállítások közötti éles vágások helyét átvették a képek közötti észrevehetetlen átmenetek, a vágás múvészete pedig már nem a beállítások szelektálását és jelenetekbe rendezését, hanem azok szétbontását és újra összeállítását jelenti, pixelek és rétegek elemzését és dinamikus képekbe foglalását, melyek részleteit egymástól függetlenül, folyamatosan lehet változtatni, idôbeli kötöttségek nélkül. A filmtörténet kezdetei óta a beállítást vagy az állóképet tekintik a filmnyelv alapegységének, ám a digitális képfeldolgozás mindkettố jelentôségégét csökkentette. Nehéz dolga lenne annak a filmszemiotikusnak, aki Christian Metz híres, nagy szintagmatanját - az egyértelmú idôbeli és térbeli diszkontinuitások alapján beazonosított filmszegmensek taxonómiáját - szeretné a mai filmeken alkalmazni. ${ }^{[23]}$ Beállítások, jelenetek, a vágás hagyományos módjai nem tûntek ugyan 
teljesen el, a kortárs hollywoodi filmek jelentôs része alkalmazza ezeket, de ma már ez csak egy lehetôség, a „narratív módszerek” egyike a sok közül.

Az úgynevezett „PowerPoint film” jól példázza a hagyományos és új narratív módokat vegyítő „metafilm” kategóriáját. A leghíresebb, minden bizonnyal, Al Gore grafikonokat, térképeket, statisztikai adatokat, fényképeket, rajzokat és filmképeket is tartalmazó, Kellemetlen igazság (An Inconveniant Truth. Davis Guggenheim, 2006) címú filmje; Michael Wels YouTube-on közzé tett oktatófilmjei, a The Machine is Us/Ing Us (2007) és az An Anthropological Introduction to YouTube (2008) szintén jó példák. ${ }^{[24]}$ Nem meglepô módon, a PowerPoint filmek mobiltelefonos filmfesztiválokon is szerepelnek. Példaként emlithetjük David Bakker A Short History of Nearly Everything (David Bakker, 2008) címú, Bill Bryson 624 oldalas könyvét négy percben összefoglaló filmjét, mely szerepelt a 2008-ban megrendezett groningeni Viva La Focus fesztiválon. Az Objet à usages multiples (Delphine Marceau, 2008) címú, viszonylag hagyományos módon rögzített és vágott mobiltelefonos film a különbözô médiák fentebb említett konvergenciáját kifigurázva, hétköznapi használati tárgyaknak az eredetitôl eltérô funkcióban történô használatát mutatja be. Természetesen maga az okostelefon is ezek közé tartozik manapság. [25]

Sok más példa közül kiemelem még Henry Reichold Free Run címú, a 2007-es párizsi Festival Pocket Films alkalmával bemutatott, „remix” mobiltelefonos filmjét. ${ }^{[26]}$ A londoni metróból kilépó és a kamera irányába sétáló utazó tömeget ábrázoló dokumentarista nyitókép után a város nevezetességeit és forgalmát bemutató mozgó- és állóképeket, filmeket, fényképeket, animációkat, rajzokat és képeslapokat látunk, ahogy a főszereplő átgördeszkázik a városon. A film ügyesen foglalja össze a filmtörténetet: a Lumière-testvérek A munkások kilépnek a gyár kapuján (Sortie des usines Lumière, 1895) címú, az ipari kort summázó filmjére nyilvánvalóan utaló nyitójelenettôl kezdve, a film remix-jellegén át, az erôsen individuális, egyéni és szubjektív gördeszkás mozgásformáig, ami a posztindusztriális és posztmodern érát jelképezi, valamint a kor digitális és kommunikációs technológiáit, amelyek által megjelenítódik. A Free Run azt szemlélteti, hogy manapság ugyanúgy létre lehet hozni mozgóképet számítógéppel, mint kamerával, sôt még annál inkább. Ugyanakkor, bár mobiltelefonos filmfesztiválon mutatták be, a filmet bizonyára nem mobiltelefonnal vették fel, és arra sincs okunk, hogy azt feltételezzük, mobiltelefonos lejátszásra készült. A Free Run voltaképpen nem más, mint a filmmúvészet „zsebtörténete”.

A PowerPoint filmek ugyanakkor más értelemben is példázzák azt, ahogyan a „film elhagyja a mozit”. A moziterem falain kívül a (vegyes) mozgóképek fó funkciója már nem a történetmesélés, nem olyan karakterek bemutatása, akivel a nézó azonosulni tud, nem olyan események, kalandok és románcok ábrázolása, melyekbe a nézô belemerülhet. Épp ellenkezóleg, a mozi falain kívül a mozgókép feladata, hogy tájékoztasson, szórakoztasson, elcsábítson, hatást gyakoroljon, meggyốzzön, vagy éppen sokkoljon. Vagyis legfontosabb feladata már nem a reprezentáció, hanem a kommunikáció. A mozgókép a városi és építészeti környezet részévé vált, melyben a „Las Vegas-i lecke"- miszerint az épület megjelenése nem az épület szerkezetét és funkcióját mutatja meg, ahogyan azt a modernista építészet alapelvei diktálnák, hanem elsôsorban a kommunikációt szolgálja - már általános tudássá vált, a kommunikáció pedig elôbbre való, mint a reprezentáció. [27 ] 
Mivel a városi és hétköznapi környezet tele van a figyelmünkért versengó ingerekkel, a filmszínházakon és a nappalikon kívül jobb, ha a képernyôk nem összetett, inkább feltûnô módon kommunikálnak. Eisenstein elképzelése a montázsról, mint a néző „arculcsapása”, relevánsabb a kortárs vizuális kultúrában, mint a valós reflektív feltárulásaként elgondolt bazini filmkép. És mivel a képnek elôször is önnön jelenlétét kell kommunikálnia, ezért a médium, szó szoros értelemben, üzenetté vált.

A keitai, vagyis a 3G telefonok használata terén, Japánban és más Délkelet-ázsiai országokban, például Dél-Koreában végzett kutatások arra jutottak, hogy a felhasználók azért küldenek fényképet vagy videót kortársaiknak, családtagoknak vagy kollegáknak, hogy tanácsot kérjenek ruhavásárláskor, segítséget egy megoldandó feladathoz, hogy felhívják a figyelmet egy érdekes vagy szórakoztató történetre, vagy egész egyszerúen tudassák a másikkal, hogy gondolnak rá. Gyakran maga a tartalom nem is annyira lényeges, sốt elhanyagolható az üzenettel kifejezni kívánt szándékhoz képest: a kommunikáció elóbbre való, mint a reprezentáció. ${ }^{[28]}$ Mindennek persze megint csak kevesebb köze van a képek létrehozásához és megosztásához használt médiumhoz vagy technológiához, mint azokhoz a pragmatikus és gyakorlati körülményekhez, amelyek között terjednek és kommunikálnak ezek a képek.

\section{iPhone és Youtube}

Hová soroljuk a mobiltelefonos filmet a filmtípus vagy a filmes múfaj tekintetében? Elôször is eléggé egyértelmúnek tûnik, hogy a mobiltelefonos film a médiumokra általában kiterjedô „remediatizációs” folyamatban vesz részt, amely nem korlátozódik a filmre. A mozgókép a digitális metamédium nyersanyagává vált: minden más médiummal keveredhet, vegyülhet, ráadásul gyártása, tárolása, forgalmazása és bemutatása már nem kötődik specifikus csatornákhoz, felületekhez. Vagyis a mobiltelefonos filmek nem feltétlenül mobiltelefon kamerájával készülnek: a mobiltelefonos filmfesztiválokon részt vevô alkotások jó része tartalmaz számítógép-generálta animációt, speciális effektet, nem filmes képből, grafikából, szövegbool és tipográfiából álló kollázst. A mobiltelefonos filmek nem is kizárólag mobiltelefonon történô lejátszásra készülnek. Mivel a mobilkijelzók más, nem moziban található képernyôkhöz hasonló technológiai és pragmatikus korlátokkal bírnak, ezek a filmek ugyanúgy megjelenhetnek a nagyvárosi óriásképernyôkön, image skineken, tömegközlekedési eszközökön felszerelt monitorokon, hordozható eszközökön, közterületen vagy bevásárlóközpontokban elhelyezett kijelzôkön. A mobiltelefonos filmfesztiválok fokozatos visszaszorulásának egyik oka talán éppen abban rejlik, hogy a mobiltelefonos film beolvad az általános digitális médiakultúrába.

A mobiltelefonos filmfesztiválok résztvevőinek „szociológiai” háttere kevéssé tanulmányozott aspektus. A szervezők és a zsûritagok általában médiaszakemberek: filmrendezók vagy producerek, filmkritikusok vagy filmmúzeumok kurátorai. A versenyfilmek jelentôs részének formátuma, megjelenése és kvalitásai messze nem amatôr filmesekre utalnak. Bár a résztvevốk szakmai hátterérôl ritkán esik szó, a címek, a kompozíció, a vágás, a hangeffektek és a technikai 
kvalitások arra engednek következtetni, hogy az indulók szakmai képzésben részesültek, és rendelkeznek némi tapasztalattal a forgatókönyv, a színészek irányítása, a színrevitel, a filmes felszerelések és a vágó szoftverek használata terén egyaránt. Érdemes tehát ebból a szempontból is összevetni a különbözố fesztiválokon, például a brüsszeli Cinépocket-en vagy a párizsi Festival Pocket Films-en szereplô alkotásokat a groningeni Viva la Focus résztvevôivel. Míg az elsô két fesztiválon inkább profi alkotásokat láthatunk, Groningenben elsôsorban a régióban élố középiskolások és fiatalok által készített alkotások tekinthetôk meg. A két, különbözô típusú fesztivál körülbelül úgy viszonyul egymáshoz, mint a Vimeo a YouTube-hoz. Vagyis, az egyik esetben szakmabeliek által irányított fesztiválról beszélünk, míg a groningeni esemény inkább egy mindenki elött nyitott platform, ahol a részt vevô alkotásokat nem szúrik szakmai szempontok alapján. Talán nem véletlen, hogy a filmfesztiválokra nevezett alkotásokat általában nem lehet a YouTube-on megtalálni.

Amennyiben tehát a mobiltelefonos filmfesztiválok legfontosabb funkciója az új filmkészítési módnak a hagyományos filmmúvészetbe történô integrálása, úgy tûnik, hogy e fesztiválok eleve vesztett csatát vívnak. A mobiltelefonos filmek a digitális média világát gazdagítják, s ilyen értelemben ezek az alkotások nem tekinthetôk a filmmúvészet valamiféle kiterjesztésének vagy toldalékának. Emlékezzünk csak Odin megjegyzésére, aki szerint a „zsebfilmek közönsége” tudatos nézókből áll, akik a kortárs mainstream alkotásokhoz a gyártási eszközök és technológiák mentén közelítenek. Ez azt jelenti, hogy a mobiltelefonos filmek és fesztiválok olyan játszóteret vagy gyakorló terepet biztosítanak a jövendôbeli filmrendezôk és nézôk számára, ahol mindenki begyakorolhatja a digitális metamédium jelentette jövôbe vezetô, látványos „free run” elemeket. Ha ezt elfogadjuk, akkor a mobiltelefonos filmfesztiválok utat mutatnak a jövóbe, fokozatos térvesztésük pedig saját sikerük jele.

Másfelôl viszont a mobiltelefonos filmfesztiválok határvonalat is igyekeznek húzni a professzionális filmkészítés és a legmarkánsabban a YouTube által képviselt, egyre népszerúbb csináld magad filmes kultúra közé. Alapvetô üzenetük ugyanis az, hogy bár gazdasági és elvi síkon a filmkészítés gyakorlata ma már mindenki számára hozzáférhetô, érdekes filmek készítéséhez nem elég egy mobilkamera és egy olcsó, felhasználóbarát szoftver. Annak ellenére tehát, hogy bárki nevezheti alkotását, mégis igyekeznek kizárni a professzionális filmkészítők soraiból az ajtajukon kopogtató amatôröket. S ez egyfajta, a YouTube-ra adott válaszként is értelmezhető. Egyelöre még a jövố titka, hogy a mobiltelefonos filmfesztiválok visszaszorulása azt mutatja-e, hogy ez a csata is elveszett.

[A szöveg eredeti megjelenési helye: Jan Simons: Between iPhone and YouTube: Movies on the Move? In Video Vortex Reader 2: Moving Images Beyond YouTube. Szerk. Geert Lovink és Rachel Somers. Amsterdam, Institute of Network Cultures, 2011. 95-107.]

Fordította Karácsonyi Judit 


\section{Jegyzetek}

1. conScoreReleases 2010. május U.S. Online Video Rankings.

2. Terdiman, Daniel: A Celebration of Cell-Phone Film. Wired, 2004. augusztus 30. http://www.wired.com/culture/lifestyle/news/2004/08/64698;

3. Cinema at your fingertips. Festival Pocket Films Paris, 2005. http://www.festivalpocketfilms.fr/english/archives-98/article/2005-edition.

4. Más filmek szintén maguknak vindikálják „az elsô játékfilm hosszúságú, teljes egészében mobil kamerával felvett filmnek" járó tiszteletbeli címet. Példaként említhetjük a holland rendező, Cyrus Frisch Why Didn't Anybody Tell Me It Would Become This Bad in Afghanistan (2007) címú filmjét. Az elsô, kizárólag mobiltelefonon terjesztett fontosabb film pedig (állítólag) a Sally Potter 2009-ben forgalomba hozott Rage címú alkotása. A bizonytalanságot valószínúleg az SMS Sugar Man 2005. decemberi forgatása és 2008-as forgalmazása közötti idôbeli eltérés okozza.

5. Létezett egy igen rövid életû Dogma Mobiltelefonos Nemzetközi Filmfesztivál. A Dogma és Lars von Trier kapcsán ld. Simons, Jan: Playing The Waves: Lars von Trier's Game Cinema. Amsterdam, Amsterdam University Press, 2007.

6. Keen, Andrew: The Cult of the Amateur: How Today's Internet Is Killing Our Culture. New York, Doubleday, 2007.

7. Mobile Film Festival: http://de.mobilefilmfestival.com/teilnahmebedingungen.php; Festival Pocket Films: www.festivalpocketfilms.fr/rubrique.php3?id_rubrique=4\&var_mode=recalcul; Mobifest: http://www.mobifest.net/home/.

8. http://www.festivalpocketfilms.fr/archives/edition-2005/.

9. Odin, Roger: Le „Pocket Film Spectateur”. Festival Pocket Films, 2009. http://www.festivalpocketfilms.fr/communaute-42/reflexions/article/le-pocket-film-spectateur-par.

10. http://cinepocket.lescorsaires.be/spip.php?article40.

11. Pierce, Juliana: Feature: The Fourth Screen. Off The Air: Screenrights' Newsletter, 2005. augusztus. http://www.screen.org/pdfs/about/offtheair/2005/ota0805.pdf.

12. Wolf, Reinhard W.: Micromovies - Kurzfilme für die Westentasche, Teil 1. Shortfilm.de Das Kurzfilmmagazin, 2006. január 2. http://www.shortfilm.de/index.php?id=414\&L=0\&0=.

13. Terdiman idézi, in A Celebration of Cell-Phone Film. A mobiltelefonos filmezés "alapjairól”, ld. még: Curry, Neil: Film-maker Shares Secrets of Great Mobile Phone Movies. CNN, 2009. március 20. http://articles.cnnn.com/2009-03-20/entertainment/mobilemovies.toptips_1_mobile-phone-videoquality-regular-camera?-s=PM:SHOWBIZ.

14. Green Porno (Rossellini, Isabella, Shapiro, Jody és Rick Gilbert (producerek), USA, 2008.) http://www.sundancechannel.com/greenporno/.

15. http://www.youtube.com/watch?v=mkm3CCX1_xk.

16. Az érvelés aktuálisabb megfogalmazását ld. Benoît Labourdette: Tournez Un Film Avec Votre Téléphone Portable. Editions Dixit, 2008.

17. A remediatizáció [remediation] fogalma Jay David Boltertôl és Richard Grusintól származik. In Remediation: Understanding New Media. Cambridge, Mass., The MIT Press,1999. Magyarul lásd A remedializáció hálózatai. Ford. Babarczi Katica. Apertúra, 2011. tavasz. URL: http://apertura.hu/2011/tavasz/bolter-grusin 
18. Odin: i.m.

19. Munt, Alex: S, M, X, XL: The Question of Scale in Screen Media. Flowtv 6.8, http://flowtv.org/?p=809\#.

20. Brown, Tod: Isabella Rossellini Does Bug Porn. Twitch, 2008. január 1. http://twitchfilm.net/site/view/isabella-rossellini-does-bug-porn/.

21. Lásd Beekmans, Jeroen: Turing Times Square Into Art Square. The Pop-Up City, 2009. december 21. URL: http://popupcity.net/2009/12/turning-times-square-into-art-square/; Mirjam Struppek: Urban Screens The Urbane Potential of Public Screens for Interaction. Intelligent Agent, 6. 2: Interactive City. URL: http://www.intelligentagent.com/archive/vol6_No2_interactive_city_struppek.htm.

22. Manovich, Lev: Understanding Hybrid Media. 2007. http://www.manovich.net.

23. Metz, Christian: Essais Sur La Signification au Cinéma, Tome 1. Paris, Klincksieck, 1983.

24. Welsh, Michael: The Machine Is Us/Ing Us, 2007. URL: http://www.youtube.com/watch?v=6gmP4nk0EOE; An Anthropological Introduction To YouTube, 2008. URL: http://www.youtube.com/watch?v=TPAO1Z4_hU\&feature=channel; Bakker, David: $A$ Short History of Nearly Everything, 2008. URL: http://www.vivalafocus.nl/archief/2008/films/a-short-history-of-nearly-everything-3gp.

25. Objets à Usages Multiples (Delphine Marceau, 2008). URL : http://www.festivalpocketfilms.fr/films/article/objets-a-usages-multiples.

26. http://www.festivalpocketfilms.fr/films/article/free-run.

27. Venturi, Roberto, Brown, Denise Scott és Izenour, Steven: Learning From Las Vegas: The Forgotten Symbolism of Architectural Form. Cambridge, Mass., The MIT Press, 2001.

28. Ito, Mizuko, Okabe, Daisuke és Matsuda, Misa (szerk.): Personal, Portable, Pedestrian: Mobile Phones in Japanese Life. Cambridge, Mass., The MIT Press, 2005.

\section{Irodalomjegyzék}

- Bolter, Jay David és Richard Grusin: Remediation: Understanding New Media. Cambridge, Mass., The MIT Press, 1999.

- Brown, Tod: Isabella Rossellini Does Bug Porn. Twitch, 2008. január 1. URL: http://twitchfilm.net/site/view/isabella-rossellini-does-bug-porn/

- Beekmans, Jeroen: Turing Times Square Into Art Square. The Pop-Up City, 2009. december 21. URL: http://popupcity.net/2009/12/turning-times-square-into-art-square/.

- Curry, Neil: Filmmaker Shares Secrets of Great Mobile Phone Movies. CNN, 2009. március 20. URL: http://articles.cnnn.com/2009-03-

20/entertainment/mobilemovies.toptips_1_mobile-phone-video-quality-regular-camera?s=PM:SHOWBIZ.

- Ito, Mizuko, Daisuke Okabe és Misa Matsuda (szerk.): Personal, Portable, Pedestrian: Mobile Phones in Japanese Life. Cambridge, Mass., The MIT Press, 2005. https://doi.org/10.7551/mitpress/5309.001.0001

- Keen, Andrew: The Cult of the Amateur: HowToday's Internet Is Killing Our Culture. New York, Doubleday, 2007.

- Labourdette, Benoît: Tournez Un Film Avec Votre Téléphone Portable. Editions Dixit, 2008.

- Manovich, Lev: Understanding Hybrid Media. 2007. http://www.manovich.net.

- Metekohy, Mark: YouTube Statistics. Viralblog, 2010. május 17. URL: http://www.viralblog.com/research/youtube-statistics. 
- Munt, Alex: S, M, X, XL: The Question of Scale in Screen Media. Flowtv, 6.8. URL: http://flowtv.org/?p=809\#.

- Metz, Christian: Essais Sur la Signification au Cinéma. 1. kötet. Paris, Klincksieck, 1983. Odin, Roger: Le „Pocket Film Spectateur”. Festival Pocket Films, 2009. URL:

http://www.festivalpocketfilms.fr/communaute-42/reflexions/article/le-pocket-filmpectateur-par.

- Pierce, Juliana: Feature: The Fourth Screen. Off The Air: Screenrights' Newsletter, 2005. augusztus. URL: http://www.screen.org/pdfs/about/offtheair/2005/ota0805.pdf.

- Simons, Jan: Playing The Waves: Lars von Trier's Game Cinema. Amsterdam, Amsterdam University Press, 2007.

https://doi.org/10.5117/9789053569795

- Struppek, Mirjam: Urban Screens - The Urbane Potential of Public Screens for Interaction. Intelligent Agent, 6. 2: Interactive City. URL:

- http://www.intelligentagent.com/archive/vol6_No2_interactive_city_struppek.htm.

- Terdiman, Daniel: A Celebration of Cell-Phone Film. Wired, 2004. augusztus 30. URL: http://www.wired.com/culture/lifestyle/news/2004/08/64698.

- Venturi, Roberto, Denise Scott Brown és Steven Izenour: Learning from Las Vegas: The Forgotten Symbolism of Architectural Form. Cambridge, Mass., The MIT Press, 2001.

- Wolf, Reinhard W.: Micromovies - Kurzfilme für die Westentasche, Teil 1. Shortfilm.de Das Kurzfilm-magazin. 2006. január 2. URL: http://www.shortfilm.de/index.php?id=414\&L=0\&0=. 
(C) Apertúra, 2019. tél | www.apertura.hu

webcím: https://www.apertura.hu/2019/tel/simons_az-iphone-es-a-youtube-kozott-a-filmek-

$\underline{\text { mozgasban/ }}$

https://doi.org/10.31176/apertura.2019.14.2.3

(Q)opertúro 